\title{
Fish assemblages and their ecological traits along an elevational gradient in the Río Pacuare, Costa Rica
}

\author{
Jorge Picado Barboza ${ }^{1} \&$ Gerardo Umaña Villalobos ${ }^{2}$ \\ 1. Instituto Costarricense de Electricidad; jpicado@ice.go.cr \\ 2. Universidad de Costa Rica; gerardo.umana@ucr.ac.cr
}

Received 16-I-2017. Corrected 04-VIII-2017. Accepted 01-I-2018.

\begin{abstract}
Fish assemblages and their ecological traits along an elevational gradient in the Río Pacuare, Costa Rica. Between May 2004 and May 2005, we sampled fish in 19 sites, grouped in four elevations, ranging from the river mouth to 650 m.a.s.l. in the Río Pacuare, Caribbean versant of Costa Rica. Changes in the distribution and composition of the fish fauna, as well as patterns of alpha and beta diversity along an elevational gradient were assessed. Additional analyses of habitat preferences, trophic guilds, functional groups and general ecology for the most abundant species are included. All fish captured were classified into 22 families, 43 genera and 53 species. The most abundant family was Characidae, followed by Gobiidae, Mugilidae, Poeciliidae and Heptateridae, which together comprise $87.9 \%$ of all sampled individuals. Elevation shows an inverse effect on species diversity, we observed a monotonic decrease in species richness with increasing elevation $(\mathrm{p}<0.05)$, as reported in other tropical rivers. According to our results, in the Río Pacuare the total fish fauna diversity is found within the first 500 m.a.s.l. Species turnover increases with elevation, while nestedness decreases. Turnover was dominated by the loss of species rather than gain; the higher species loss was registered between the river mouth and the lower river reach $(<100$ m.a.s.1.). Seven species can be classified as typical or core species (Astyanax aeneus, Sicydium altum, Agonostomus monticola, Poecilia gillii, Brycon costaricensis, Rhamdia laticauda and Joturus pichardi) along the elevation gradient. The habitat availability and the integration of ecomorphological, feeding and reproductive traits help to explain better the elevation distribution of the complete set of species observed. Although it is possible to identify groups of species characteristic of each reach of river, this does not mean that they are isolated from each other. Natural drift and movement along the river of some species during their life cycle, especially S. altum, A. monticola and J. pichardi, are key processes linking the whole watershed. The present study constitutes a first step in documenting and understanding the distribution and composition of fish assemblages in a watershed that is relatively intact and well-conserved in the Caribbean versant of Costa Rica. Rev. Biol. Trop. 66(Suppl. 1): S132-S152. Epub 2018 April 01.
\end{abstract}

Key words: Pacuare River, elevation gradient, freshwater fishes, Caribbean versant.

The freshwater fish fauna of the Neotropics is the most diverse on Earth, with over 7000 species estimated for the rivers and streams of tropical South and Central America (Albert \& Reis, 2011). According to Angulo, Garita-Alvarado, Bussing \& López (2013) about 250 native freshwater fish species inhabit Costa Rica, of which 24 (10\%) are endemic. A total of 145 species is known in the Caribbean and Northern region of Costa Rica, of which only seven are restricted to those regions (Angulo et al., 2013). The latest analysis of the derivation of the freshwater fish fauna of Central America presented by Matamoros McMahan, Chakrarty, Albert \& Schaefer (2014), proposed that the Caribbean fish fauna of Costa Rica is part of an area of endemism named "Bocas," ranging from the Río Sarapiquí in Costa Rica to the western border of the Río Chagres basin in Panamá. These findings support Myers's hypothesis (1966), who proposed that species richness of freshwater fishes 
of Central America is substantially higher in areas located adjacent to the more species-rich regions of North and South America (Matamoros et al., 2014).

The influence of elevation gradients on the distribution of freshwater fishes in the Neotropics has been assessed for Andean rivers (Jaramillo, Maldonado \& Escobar, 2010; Carvajal et al., 2015; De La Barra et al., 2015). Those studies showed a monotonic decrease in species richness, while the distinctiveness of the species composition increased with elevation. At higher river reaches turnover was dominated by the loss of species rather than gain. Dominance by a few species was also greater at higher elevations. Despite these general patterns, in some regions, species richness is greatest at the headwaters owing to the cumulative number of endemic species (Carvajal et al., 2015). Physical factors such as water temperature and the severity of the physical habitat (related to the slope and river width) have been identified as possible barriers to the elevational distribution of tropical freshwater fish (De La Barra et al., 2015).

Anthropogenic effects such as habitat alteration, deforestation, pollution and exotic fish introductions, are also factors that threaten autochthonous fish diversity (Bussing, 1998; Beard, 1989; Wolter \& Arlinghaus, 2003; Wright \& Flecker, 2004). The last is apparently not the case of the Río Pacuare, which is considered one of the few watersheds in Costa Rica that is well-preserved, especially in the middle and upper reaches (Anderson, Freeman \& Pringle, 2006a; Anderson, Pringle \& Rojas, 2006b; Instituto Costarricense de Electricidad (ICE), 2006). Studying the ecology of fishes inhabiting this river is an opportunity to understand the factors that molded the assemblages under a condition of low anthropogenic alteration.

We performed a one-year sampling campaign in 19 sites grouped in four elevational reaches in the Río Pacuare, with the objective of describing changes in the distribution and composition of its fish fauna, as well as patterns of alpha and beta diversity along an elevational gradient. We also analyzed habitat preferences, trophic guilds, functional groups and general ecology for the most abundant species. We aim to contribute to the understanding of the ecology of the fish assemblages in the Río Pacuare, pursuing integrated watershed management to ensure the conservation of its present conditions.

\section{MATERIALS AND METHODS}

Study area: Sampling was performed in the Río Pacuare watershed on the Caribbean side of Costa Rica $\left(09^{\circ} 36^{\prime} 00^{\prime \prime}-10^{\circ} 18^{\prime} 00^{\prime \prime} \mathrm{N}\right.$ - $\left.83^{\circ} 41^{\prime} 00^{\prime \prime}-83^{\circ} 17^{\prime} 00^{\prime \prime} \mathrm{W}\right)$, the drainage area is $914 \mathrm{~km}^{2}$, the average rainfall ranges from 2000 to $5000 \mathrm{mmy}^{-1}$, the total length of the river main channel is $134.39 \mathrm{~km}$, its maximum elevation is 2650 m.a.s.l. and the average slope is $13 \%$. In the middle reach of the Río Pacuare one of the main commercial activities is tourism, mainly water sports, such as rafting, which is categorized as among the world's top five because the mountain scenery and river-rapids. Recreational fishing is also common among local persons of nearby communities. Land use in the lower reaches is dominated by banana plantations and extensive cattle farms. The city of Siquirres, located on the left margin of the Río Pacuare, is one of the principal urban centers in the region (Rojas, 2011).

We visited and sampled in nineteen sites. The elevational gradient that we included in the study ranges from sea level to 650 m.a.s.l. Site selection of sampling was affected by steep topography and the lack of public access to the river in some reaches. Despite these challenges, we attempted to include representative sites of the upper, middle and lower reaches of the Río Pacuare (Table 1, Fig. 1). We sampled each site at least three times from May 2004 to May 2005. The total linear distance covered is about $10200 \mathrm{~m}$, of which $3300 \mathrm{~m}$ correspond to tributaries, and $6900 \mathrm{~m}$ are from the main channel

Fish sampling: We use several types of fishing gear, including: cast nets, seines, gill nets and small hand nets. A total effort of 180 min was employed at each site, and we moved 


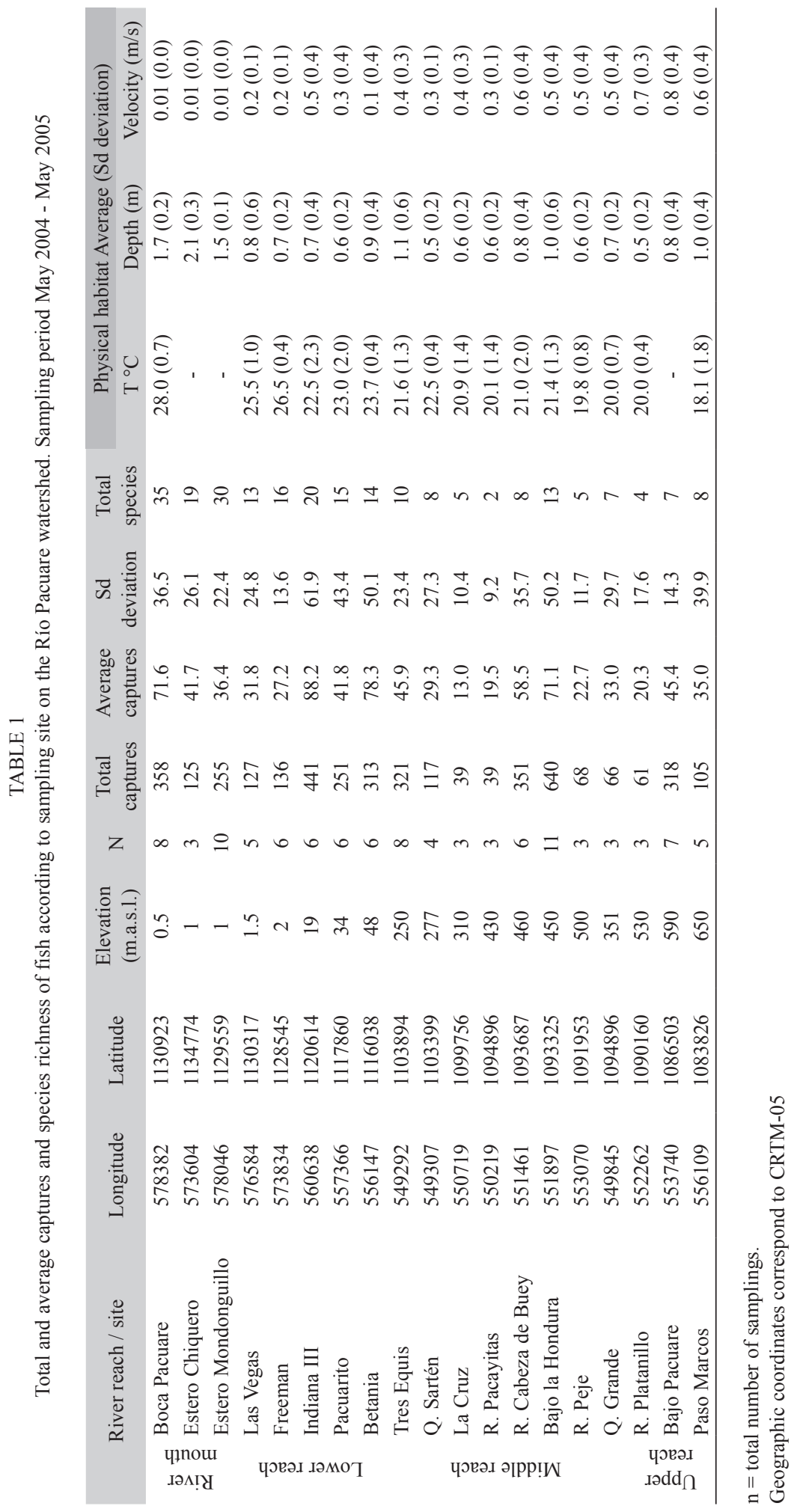




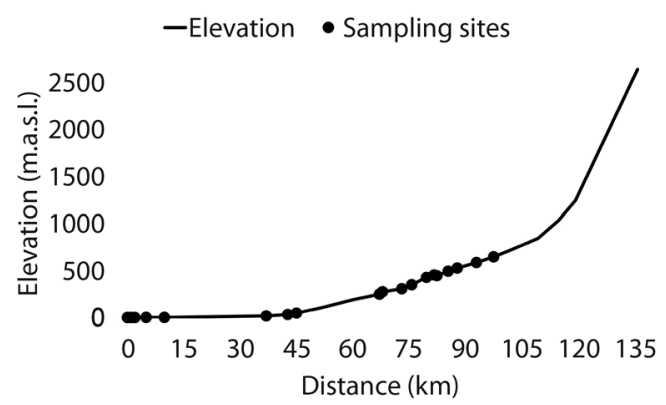

Fig. 1. Sampling sites in relation to the elevation profile of the main channel of the Río Pacuare.

upstream over a distance of $200 \mathrm{~m}$ along the main channel. At each site, sections with representative microhabitats were selected (rapids, slow current, pools, sandy bottoms and rocks). In addition, two sampling bouts were conducted with an electro-fishing device (SmithRoot $($ ) in three $15 \mathrm{~m}$ long transects, following the river margins at each site, with a maximum depth of $100 \mathrm{~cm}$. The "fish-shocker" was set to a discharge of $350 \mathrm{~V}$, with a frequency of $80 \mathrm{~Hz}$ and a working cycle of $50 \%$. Impact distance under this configuration is estimated to cover a radius of two meters.

The fish catch was placed in a plastic bucket with water and aeration from a batteryoperated aquarium aerator. Each specimen was identified to species, and its standard length (LS) recorded (Bussing, 1998). Fish were later released at the same section where they were caught. To describe the physical habitat, measurements of temperature $\left({ }^{\circ} \mathrm{C}\right)$, water velocity $(\mathrm{m} / \mathrm{s})$ and depth $(\mathrm{cm})$ were /recorded on site for every fish captured.

When the sample size allowed, up to 15 individuals for each species were collected and brought to the laboratory for gut content analysis. These were preserved with $10 \%$ formaline, and later washed with water and transferred to $70 \%$ ethanol. Fish Species were classified into five basic trophic guilds: carnivorous, herbivorous, insectivorous, detritivorous and omnivorous. Two individuals of each species were deposited at the Zoology Museum of the Universidad de Costa Rica as vouchers.

Data analysis: We performed a cluster analysis, based on Bray-Curtis similarity index, to identify patterns on species distribution and similarities among sites. An analysis of percent similarity (Simper) was employed to determine the contribution of each species to the variation between reaches of the river or tributaries of the watershed. A correspondence analysis to evaluate the effect of physical variables on the species distribution was performed. These results were used to group sites into reaches following the elevation gradient along the Río Pacuare.

We evaluated the richness completeness, or sample coverage of each river reach, using the R package Entropart. Species diversity between river reaches were compared using Hill's numbers, we followed the interpolation and extrapolation procedure proposed by Chao et al. (2014) using the R package Inext (Hsieh, Ma, \& Chao, 2016). An analysis of the significance for the rarefaction curves was performed following the method proposed by Cayuela, Gotelli, \& Colwell (2015). We tested the ecological null hypothesis that two (or more) reference samples, represented by either abundance or incidence data, were both drawn from the same assemblage of $\mathrm{N}$ individuals and $\mathrm{S}$ species, and the biogeographical null hypothesis that, regardless of differences in species composition, the profiles of two or more rarefaction curves are similar enough that they might have been drawn from assemblages that do not differ significantly in richness or in underlying species abundance distribution. Additional beta diversity and species turnover comparisons between river reaches were assessed by the method proposed by Baselga \& Orme (2012).

We evaluated changes in fish assemblage structure along the elevational gradient using rank-abundance curves, in which the abundance is plotted against the total number of species. In addition, diversity descriptive indices Shannon, Simpson and Evenness were calculated for each elevation level. A Kruskal-Wallis 
test $(\mathrm{H})$ tested for significance in the differences in total abundance and size frequency distributions for the most abundant species among river reaches. A non-parametric multifactorial analysis (Permanova), based on the Bray-Curtis similarity index, was used to test for differences in species composition among river reaches. The association between trophic guilds and elevation were explored with a correspondence analysis and evaluated using linear by linear test for ordered contingency tables. These tests were performed with the statistical packages Statistica ${ }^{\circledR}$ 6, Estimates ${ }^{\circledR}$, PAST ${ }^{\circledR}$ and R statistical computing (Clarke \& Warwick 1994; Krebs, 1994; Zar, 1999; Hammer, Harper \& Ryan, 2001; R Development Core Team, 2008; Colwell, 2013).

\section{RESULTS}

Relative abundance: 4131 fish were caught. The site with the highest catch-persample was Indiana III, with $73.2 \pm 30.7$ individuals, followed by Río Cabeza de Buey with $58.5 \pm 35.7$ and Bajo la Hondura with $54.9 \pm$ 37.7. The site with the lowest catch was $\mathrm{La}$ Cruz with $13 \pm 10.4$ individuals $(H=31.4$; $\mathrm{p}<$ 0.05 , Table 1).

All fish captured were classified into 22 families, 43 genera and 53 species. The most abundant family was Characidae, with 1329 specimens, followed by Gobiidae (1 297), Mugilidae (625), Poeciliidae (249) and Heptateridae (131). These families comprised 87.9 $\%$ of all sampled individuals (Table 2). The Cichlidae family had the highest number of species, with 13, followed by Poeciliidae with five, Characidae and Eleotridae with four species each. These four families accounted for $49 \%$ of the total number of species. The most abundant species was Sicydium altum, which accounted for $31 \%$ of the entire catch, followed by Astyanax aeneus, with $27 \%$, Agonostomus monticola with $13 \%$, Poecilia gillii $5 \%$, Brycon costaricensis $4 \%$, Rhamdia laticauda $3 \%$, Pomadasys crocro $2 \%$, Atherinella milleri $2 \%$, Roeboides bouchelei $1.6 \%$, and Joturus pichardi $1.5 \%$.
Exploratory analysis: the cluster analysis results were consistent in grouping all sites at the river mouth, followed by sites at the lower sections and some representatives of the middle sections (Tres Equis and Quebrada Sartén). Most sites of the middle reaches clustered in another group, as well as sites Bajo Pacuare and Paso Marcos that belong to the upper reaches. Finally, sites La Cruz, Río Pacayitas and Río Platanillo were clearly distinct from the main clusters (Fig. 2).

Results of the Permanova test indicated that species differences among the river sections were significant $(\mathrm{F}=4.2 ; \mathrm{p}<0.001)$. These differences were attributed by the Simper test to the species $S$. altum, A. aeneus, $A$. monticola, P. gillii, B. costarricensis, $P$. crocro, $R$. bouchellei and A. milleri, which accounted for $80.6 \%$ of the differences among the sections (Table 2).

The cluster of the species, based on their mean catch, identifies two main groups. The first is comprised of 43 species, associated mainly with the lower reaches of the river and the river mouth sites, and the second included 10 species associated with the middle and upper reaches (Fig. 3). Within the first group of species, there were 13 that accounted for most of the catch in the estuary and main channels at the river mouth (Fig. 3-G3), another subgroup of 15 species were restricted to the river mouth (Fig. 3-G2). The remaining 15 species were widespread between the river mouth and the middle reaches, six of them were shared between the lower reach and the river mouth. Another two species were only found in the middle reaches, and seven were present in other sections of the watershed, these last ones with higher abundance in the lower and river mouth reaches (Fig. 3-G1). In the second group, there were seven species with an extensive elevation distribution and high capture frequency. These species are: A. monticola, S. altum, A. aeneus, $B$. costaricensis, $R$. laticauda, J. pichardi y P. gillii, as well as three species that were caught only in the middle and upper reaches (Fig. 3-G4). 


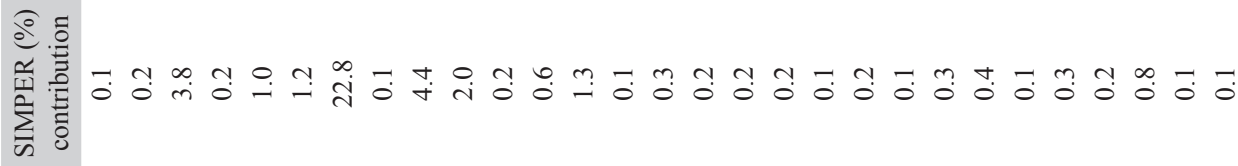

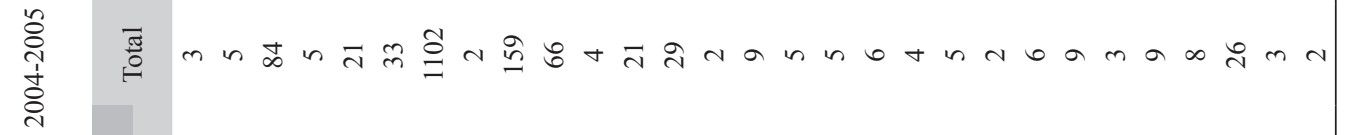

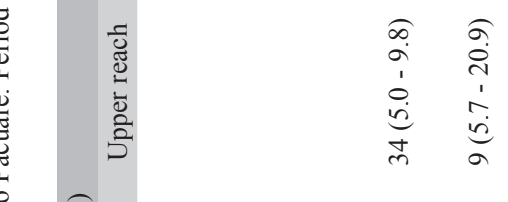

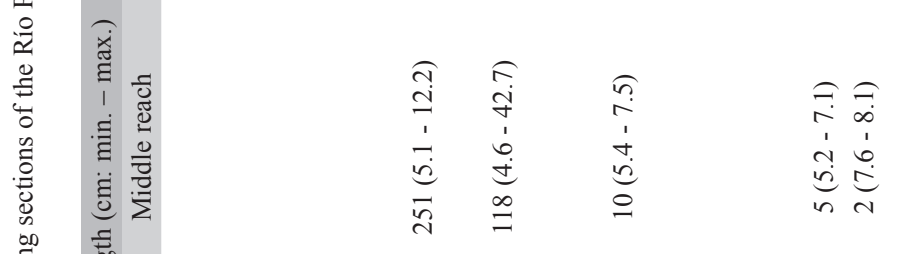

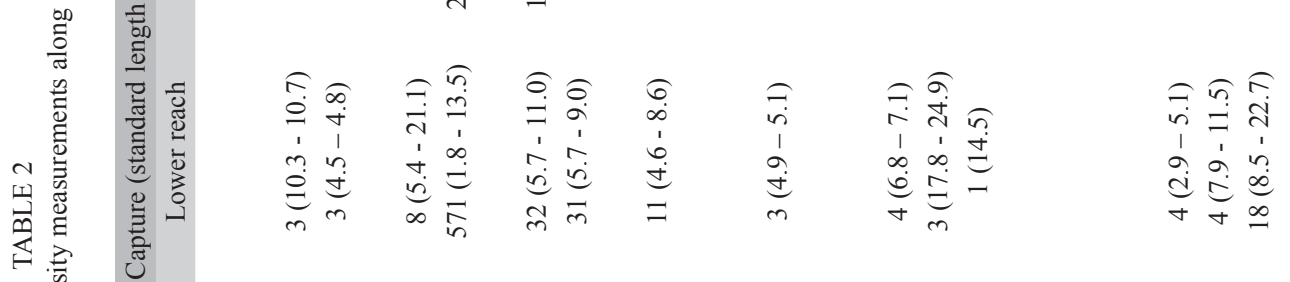

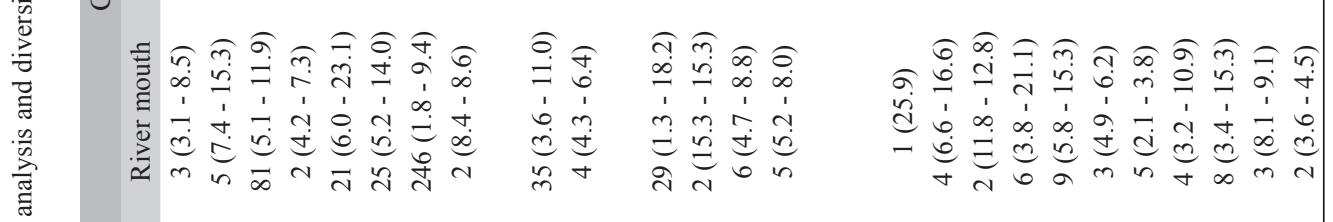

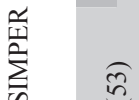

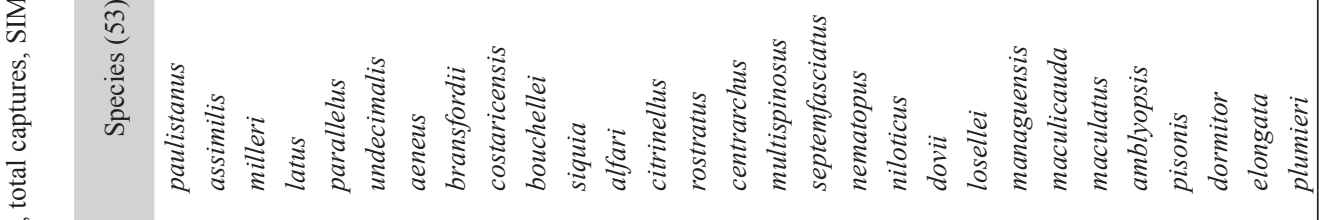

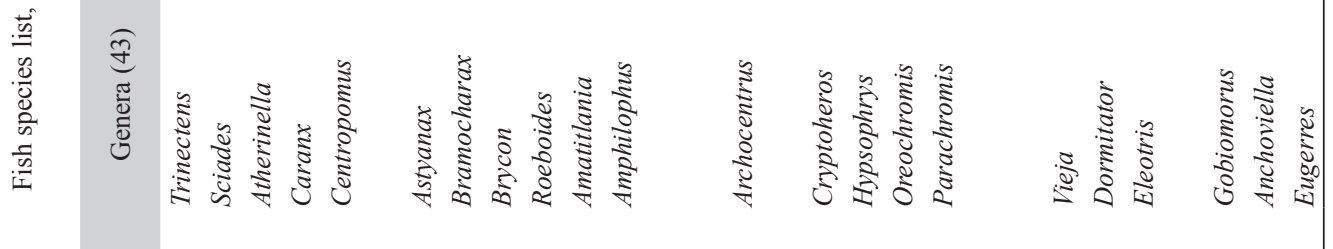

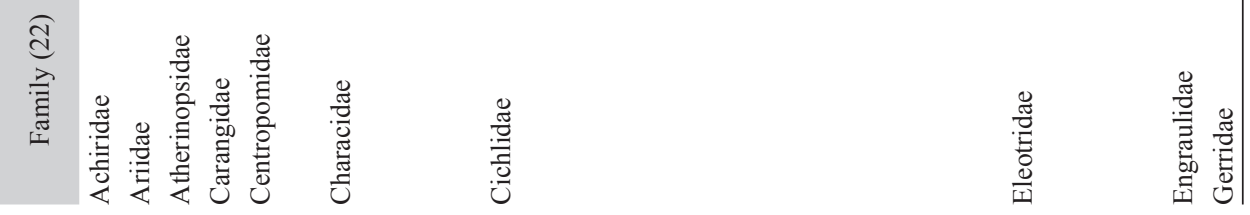




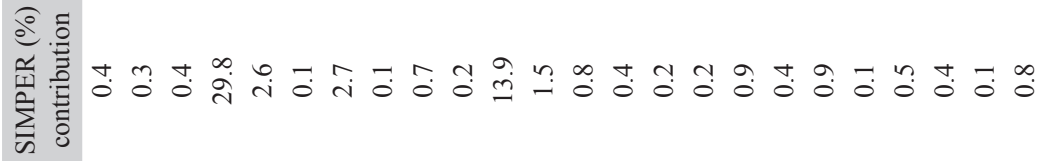

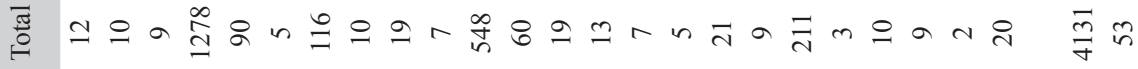

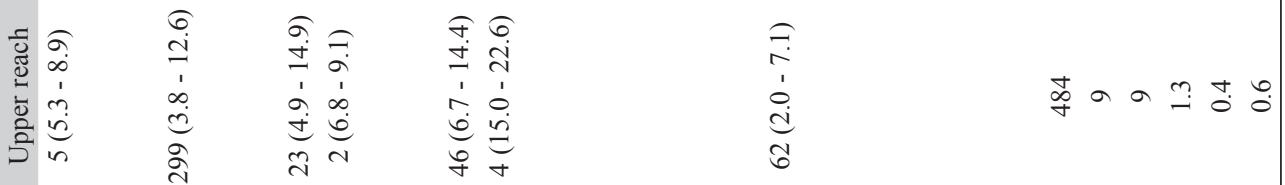

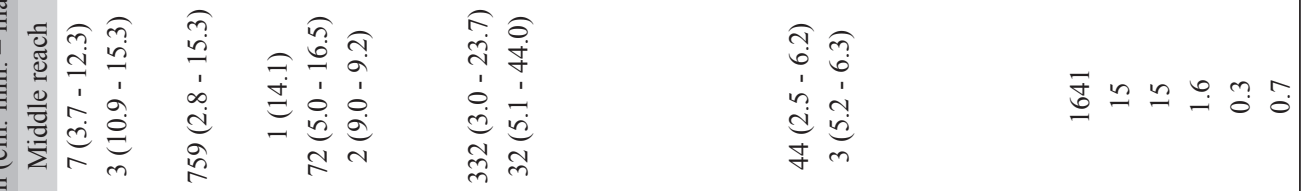

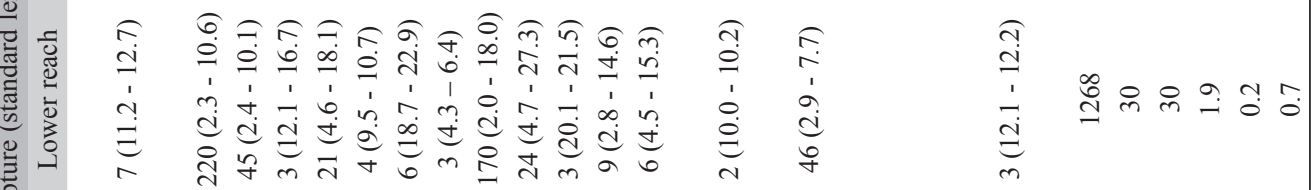

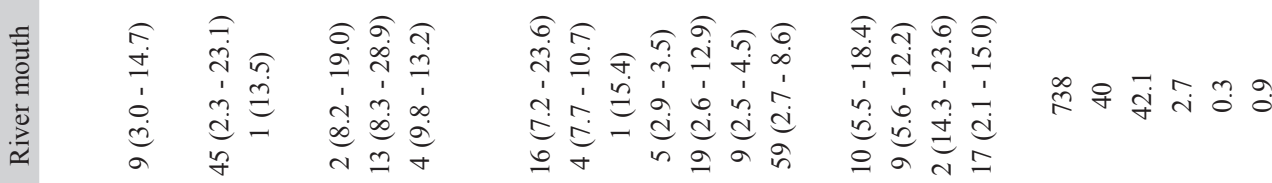

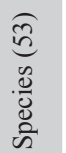

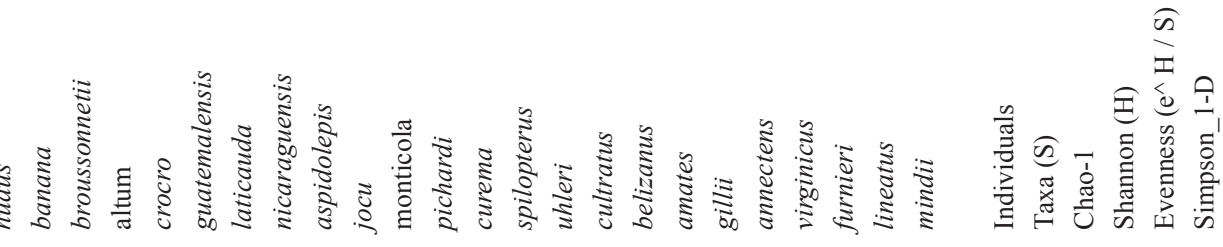

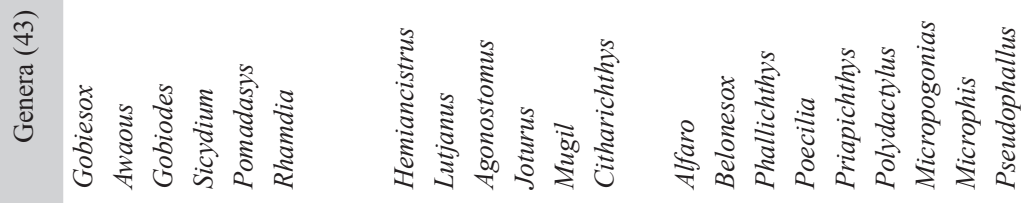

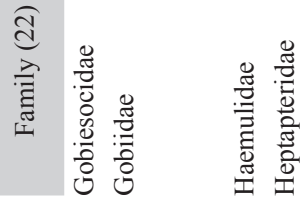

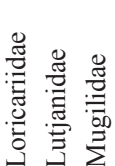

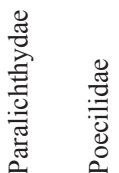

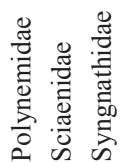




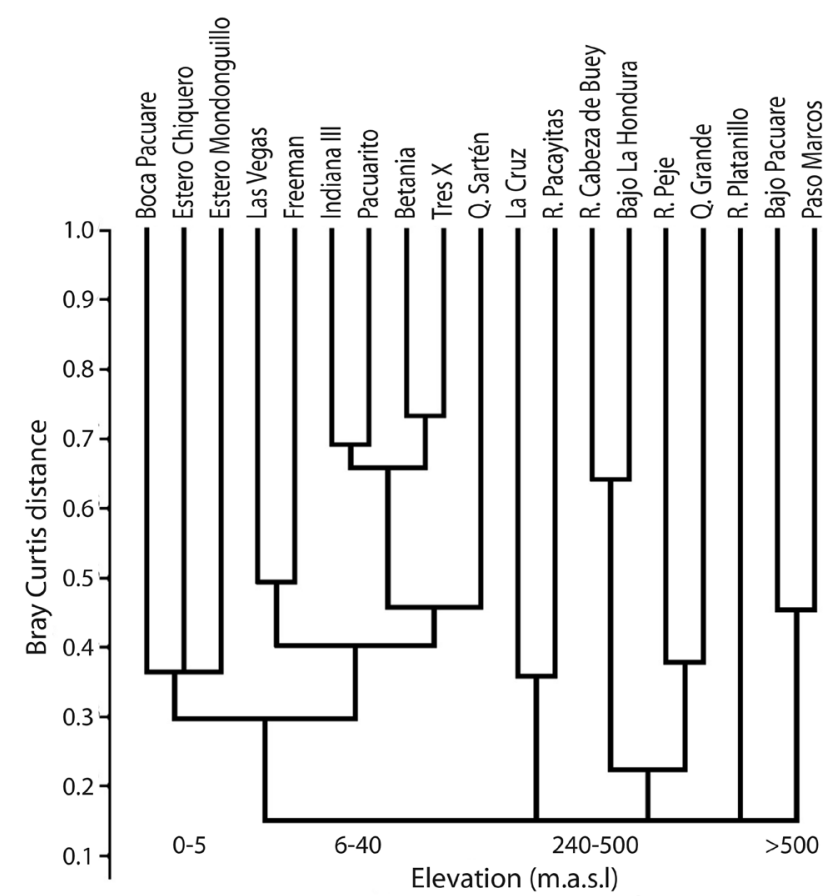

Fig. 2. Cluster analysis for sites using Bray Curtis index according to fish species composition in the Río Pacuare. Period 2004-2005. Sites follow an increasing elevation gradient from left to right.

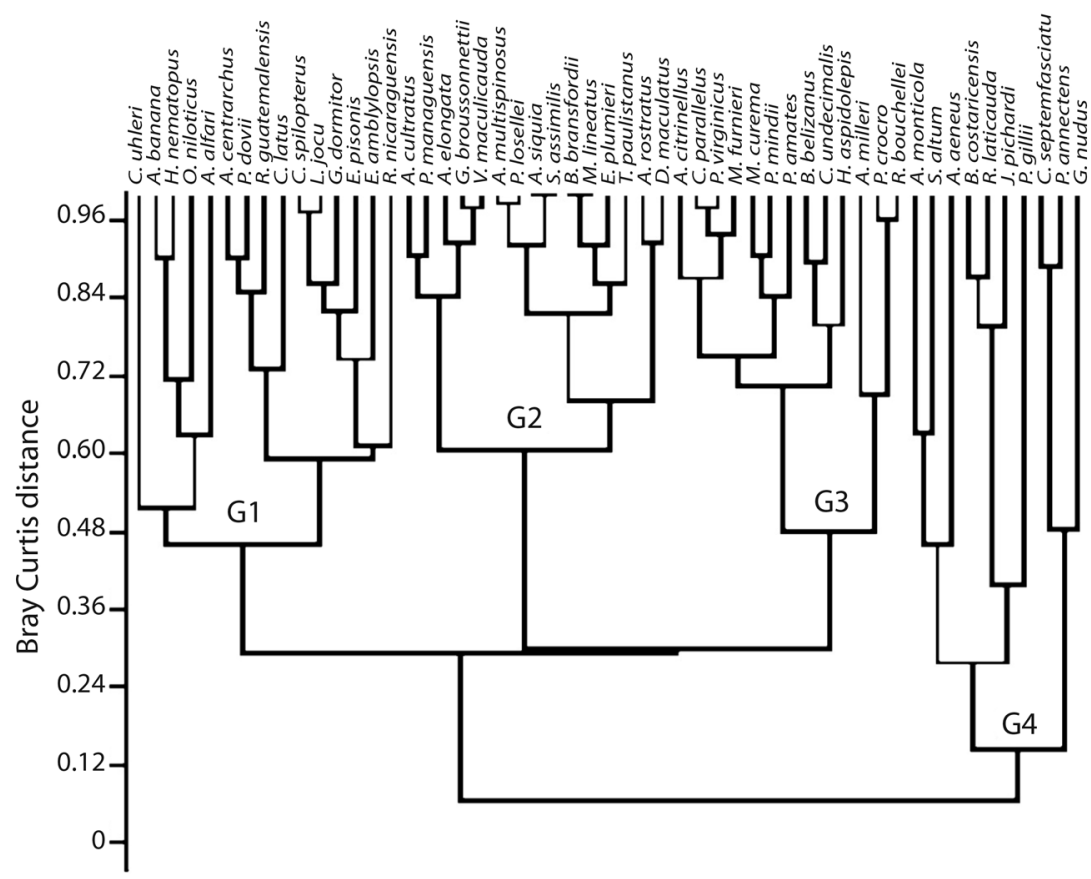

Fig. 3. Cluster analysis for fish species using Bray Curtis index according to average capture along the Río Pacuare. Period 2004-2005. Groups G1, G2 y G3 correspond to lower reach and river mouth species, G4 include species of wide distribution and frequently captured at the middle and upper reaches. 


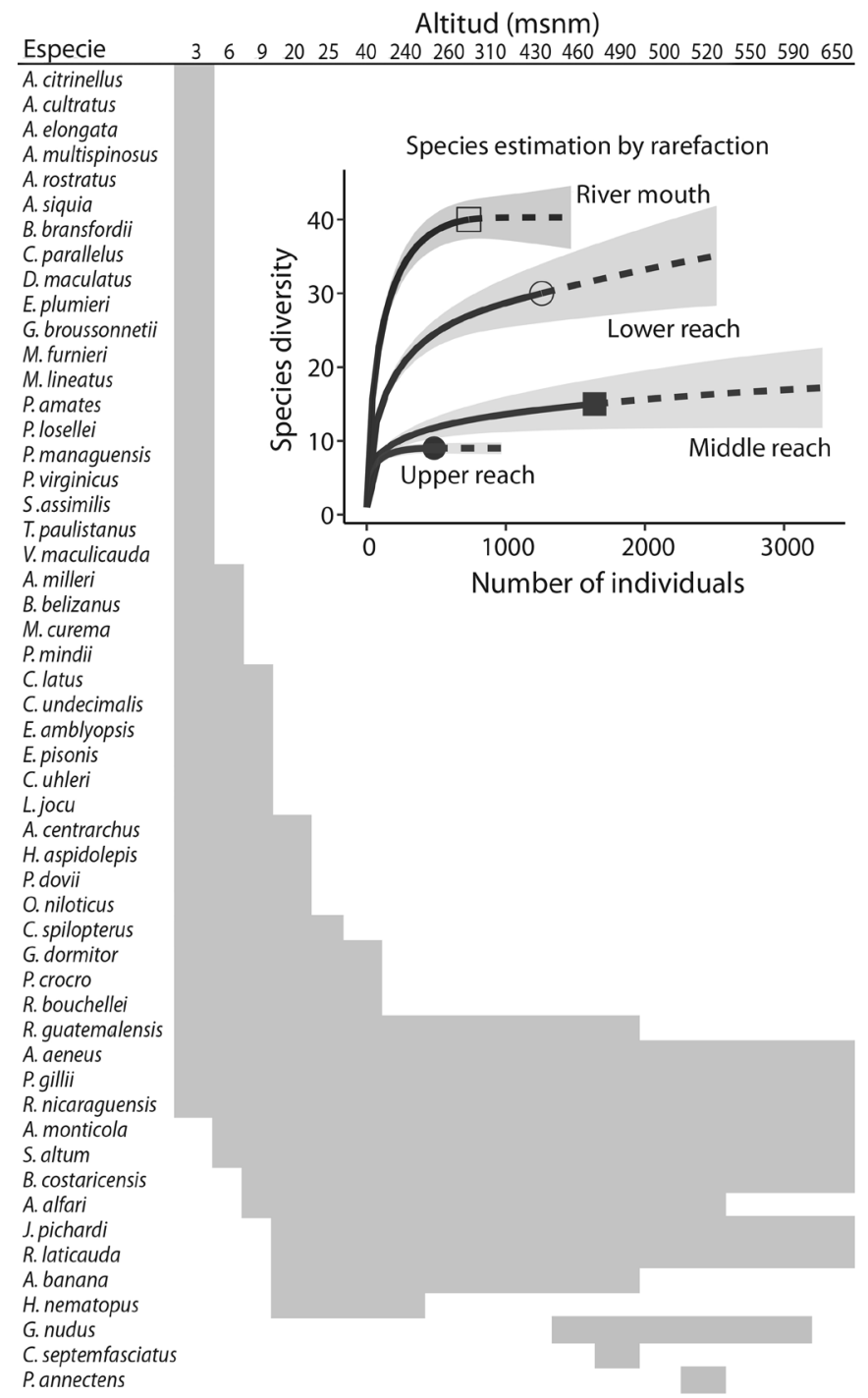

Fig. 4. Elevation fish species distribution from Río Pacuare using seriation procedure.

Box shows number of estimated species according to watershed reach. Study period 2004-2005.

According to these results, all sites were classified into four reaches following an elevation gradient, starting at the river mouth with elevations between 0-3 m.a.s.l., the lower reach between 6-40 m.a.s.l., the middle reach between 255-520 m.a.s.l. and the upper reach that groups sites between 550-650 m.a.s.1., these groups are used for the following analysis.

Species diversity: Sampling completeness among reaches was higher than 0.9 , meaning that a large proportion of the species present in each elevational band was recorded and comparisons of species diversity and composition are reliable. The estimated richness with the rarefaction method, yielded a total of 42.1 species for the river mouth, 30 for the lower reach, 15 for the middle, and nine in the upper reaches, which is nearly identical to the observed values (Table 2, Fig. 4). The ecological null hypothesis applied to Hill's numbers $\mathrm{q}^{0}$ (species richness), $\mathrm{q}^{1}$ (exponential 
of Shannon entropy) and $\mathrm{q}^{2}$ (inverse Simpson index - number of dominant species in the community) was rejected ( $\mathrm{p}<0.05$ ), supporting the general differences observed between assemblages. On the other hand, the biogeographical null hypothesis was also rejected for Hill's number $\mathrm{q}^{0}$ and $\mathrm{q}^{1}$, but not for $\mathrm{q}^{2}(\mathrm{p}=0.4)$, which suggests that within different reaches of river, dominant species have a similar relative abundance (Fig. 5).

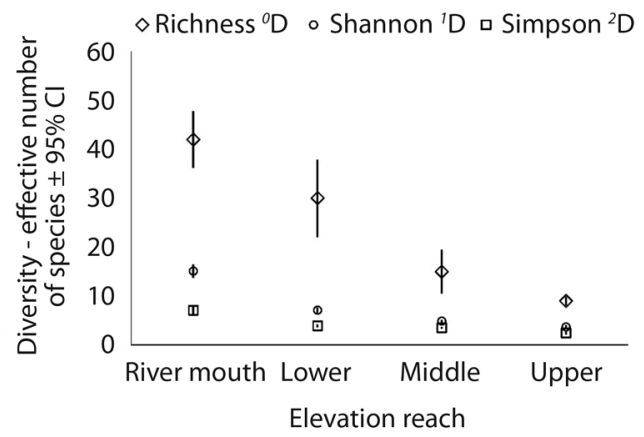

Fig. 5. Diversity expressed as Hill's numbers $\left({ }^{\circ} \mathrm{D},{ }^{1} \mathrm{D}\right.$ and $\left.{ }^{2} \mathrm{D}\right)$ according to elevational reaches for the study sites of the Río Pacuare. Period 2004-2005.

The characid $A$. aeneus and the poecilid $P$. gillii are among the dominant species at all elevations in the Pacuare watershed. The goby $S$. altum is the most common fish from the lower reach to higher elevations, and the mountain mullet $A$. monticola was also a dominant species in all sampled reaches. Other species like the grunt $P$. crocro, was common only in the lower reach and the river mouth, while the catfish $R$. laticauda presented a high abundance in the middle and upper reaches (Fig. 6).

The $\beta$-diversity analysis shows an inverse relationship between the species loss and species gain with elevation. The highest species loss was observed between the river mouth and the lower reach with a total of 20 species. Between the lower and middle reaches, 18 species were not caught, while six species were not caught between the middle and upper reaches. Only eight additional species were caught between the river mouth and the lower reach, three species between the lower and the

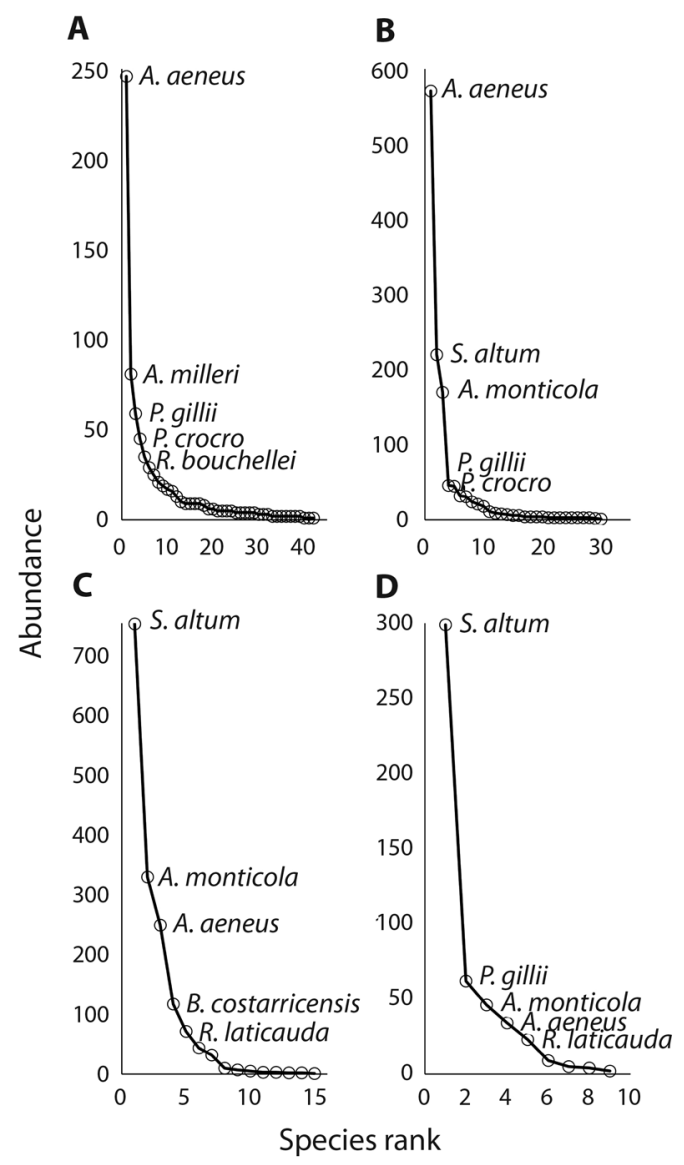

Fig. 6. Species rank abundance for each elevation reaches of the Río Pacuare. The five most abundance species are shown, A) river mouth, B) lower reach, C) middle reach and D) upper reach.

middle reach, while no additional species were caught towards the upper reach. Species turnover increases with elevation, whereas nestedness decreases. Total dissimilarity was higher between sites of higher elevation (Fig. 7).

Ecological traits: The species richness showed an inverse significant correlation with elevation and water velocity, while showing a positive correlation with temperature and water depth. Between physical variables, there is an inverse correlation among elevation, temperature and depth, while the water velocities increase in the upper reaches (Table 3). The correspondence analysis between species, sites 
TABLE 3

Correlation coefficients between species richness and physical factors of the habitat where fish were collected. Values correspond to the Pearson coefficient $\left(\mathrm{R}^{2}\right)$

\begin{tabular}{lcccc} 
& Elevation & $\mathrm{T}^{\circ} \mathrm{C}$ & Depht $(\mathrm{m})$ & Velocity $(\mathrm{m} / \mathrm{s})$ \\
$\mathrm{T}^{\circ} \mathrm{C}$ & $-0.9^{*}$ & & & \\
$\operatorname{Depht}(\mathrm{m})$ & $-0.4^{* *}$ & $0.7^{*}$ & & \\
Velocity $(\mathrm{m} / \mathrm{s})$ & $0.8^{*}$ & $-0.9^{*}$ & $-0.6^{*}$ & \\
Richness & $-0.7^{*}$ & $0.8^{*}$ & $0.7^{*}$ & $-0.7^{*}$ \\
\hline
\end{tabular}

$* \mathrm{p}<0.01, * * \mathrm{p}<0.05$

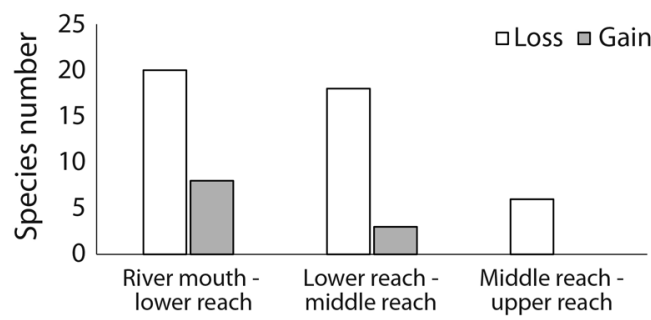

insectivorous, seven were herbivorous, five were detritivorous and four were omnivorous. The correspondence analysis between trophic guilds and elevation as well as the asymptotic linear-by-linear association test, confirm that "carnivore" is the predominant trophic guild at the lower reaches, herbivores were more common in the middle and upper reaches, insectivorous were more common with the lower

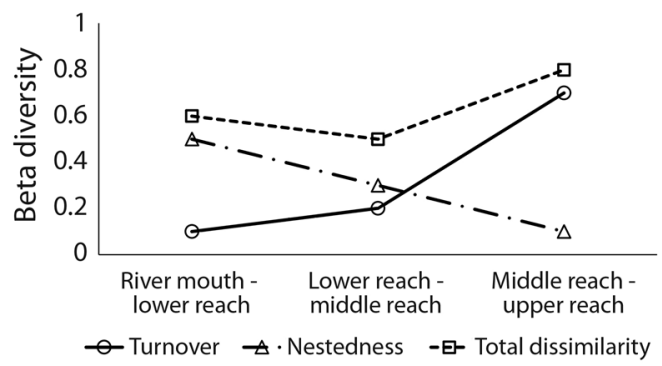

Fig. 7. Above: gain and loss in the number of species between adjacent elevation reaches. Below: $\beta$-diversity values expressed as species replacement between sites (turnover), species loss from site to site (nestedness) and total dissimilarity between adjacent elevational reaches.

and physical variables explain nearly $81 \%$ of the total variance (Fig. 8, Table 4).

Fourteen species presented an inverse response to water temperature and depth. Most of these species presented their highest abundance in the middle and upper reaches. The majority of species was captured at lower elevations. For example, nine species of Cichlidae were associated with the river mouth and lower reach, where there are higher temperature values, slow water velocity and a deeper water column.

Based on analysis of gut contents, 28 species were classified as carnivorous, nine were and middle reach, and omnivores were more common with the middle and upper reach $(\mathrm{p}<$ 0.05) (Fig. 9).

Size distributions: Size distribution of the most abundant species, based on standard length (LS) shows that for A. aeneus, larger individuals occur mainly in the middle and upper reaches $(H=346.8 ; \mathrm{p}<0.001)$. In the case of $P$. gillii, the pattern is opposite: larger individuals were captured in the lower and river mouth reaches $(H=39.4 ; \mathrm{p}<0.001)$. For $J$. pichardi, A. monticola and S. altum, we observed larger individuals in the middle and upper reaches, although this trend was not statistically significant. Finally, size distribution of $R$. laticauda and B. costaricensis did not show a discernible correlation with the sections where they were sampled (Table 5).

In February and April, we observed thousands of small fry of $S$. altum, with a mean length of $8.8 \mathrm{~mm}$, swimming upstream along the margins of the main channel in Río Pacuare. We observed this movement in the sites Betania, Siquirres and Tres Equis, although in the latter, the number of fry was considerably lower. At the same time, we observed a school of young fishes of $27.8 \mathrm{~mm}$ total length of $A$. 


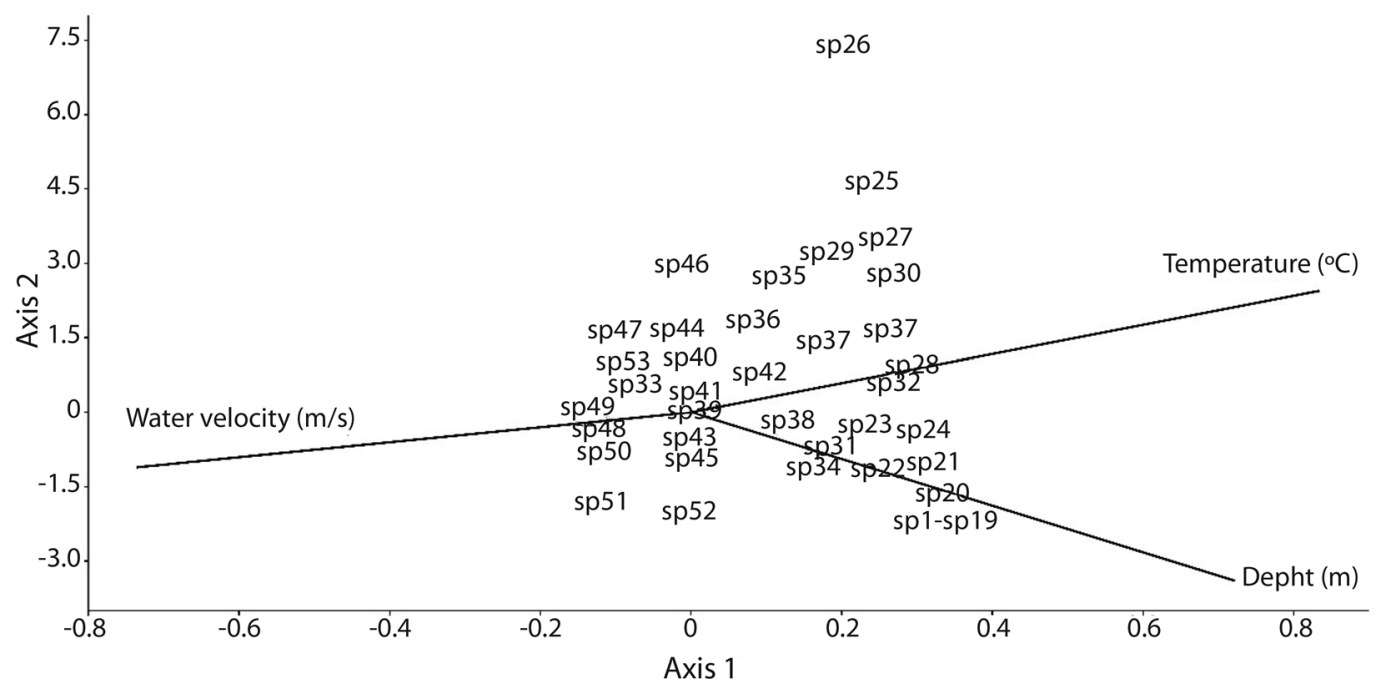

Fig. 8. Canonical correspondence for fish species and physical factors of the habitat where they were captured. Río Pacuare, period 2004-2005. Axis 1 account for $83.5 \%$ of total variance, while axis 2 account for $14.6 \%$. See table 4 for reference to species codes.

TABLE 4

Scores of the canonical correspondence analysis for fish species and physical factors of the habitat according to axis. Río Pacuare, period 2004-2005

\begin{tabular}{|c|c|c|c|c|}
\hline Factor & Code & Axis 1 & Axis 2 & Axis 3 \\
\hline A. citrinellus & sp1 & 2.90069 & -1.92774 & -0.35070 \\
\hline A. cultratus & $\mathrm{sp} 2$ & 2.90069 & -1.92774 & -0.35070 \\
\hline A. elongata & sp3 & 2.90069 & -1.92774 & -0.35070 \\
\hline A. multispinosus & sp4 & 2.90069 & -1.92774 & -0.35070 \\
\hline A. rostratus & $\mathrm{sp} 5$ & 2.90069 & -1.92774 & -0.35070 \\
\hline A. siquia & sp6 & 2.90069 & -1.92774 & -0.35070 \\
\hline B. bransfordii & sp7 & 2.90069 & -1.92774 & -0.35070 \\
\hline C. parallelus & sp8 & 2.90069 & -1.92774 & -0.35070 \\
\hline D. maculatus & sp9 & 2.90069 & -1.92774 & -0.35070 \\
\hline E. plumieri & sp10 & 2.90069 & -1.92774 & -0.35070 \\
\hline G. broussonnetii & sp11 & 2.90069 & -1.92774 & -0.35070 \\
\hline M. furnieri & sp12 & 2.90069 & -1.92774 & -0.35070 \\
\hline M. lineatus & sp13 & 2.90069 & -1.92774 & -0.35070 \\
\hline P. amates & sp14 & 2.90069 & -1.92774 & -0.35070 \\
\hline P. losellei & sp15 & 2.90069 & -1.92774 & -0.35070 \\
\hline P. managuensis & sp16 & 2.90069 & -1.92774 & -0.35070 \\
\hline P. virginicus & sp17 & 2.90069 & -1.92774 & -0.35070 \\
\hline S. assimilis & sp18 & 2.90069 & -1.92774 & -0.35070 \\
\hline T. paulistanus & sp19 & 2.90069 & -1.92774 & -0.35070 \\
\hline V. maculicauda & sp20 & 2.90069 & -1.92774 & -0.35070 \\
\hline A. milleri & $\mathrm{sp} 21$ & 2.84512 & -1.61760 & -0.48650 \\
\hline B. belizanus & sp22 & 2.75251 & -1.10069 & -0.71285 \\
\hline M. curema & sp23 & 2.65503 & -0.55657 & -0.95111 \\
\hline P. mindii & sp24 & 2.66731 & -0.62513 & -0.92109 \\
\hline C. latus & sp25 & 1.99049 & 4.57095 & -2.33718 \\
\hline
\end{tabular}


TABLE 4 (Continued)

\begin{tabular}{|c|c|c|c|c|}
\hline Factor & Code & Axis 1 & Axis 2 & Axis 3 \\
\hline C. uhleri & sp26 & 1.60041 & 7.35610 & -3.18854 \\
\hline E. amblyopsis & sp27 & 2.22647 & 2.88610 & -1.82217 \\
\hline C. undecimalis & sp28 & 2.53176 & 0.63293 & -1.16822 \\
\hline E. pisonis & sp29 & 2.13248 & 2.95106 & -2.12905 \\
\hline L. jocu & $\mathrm{sp} 30$ & 2.25055 & 2.71418 & -1.76962 \\
\hline A. centrarchus & $\operatorname{sp} 31$ & 1.44376 & -0.95450 & 1.25567 \\
\hline H. aspidolepis & $\mathrm{sp} 32$ & 2.26122 & 0.51121 & -1.09775 \\
\hline O. niloticus & sp33 & -0.37740 & 0.26206 & 3.26363 \\
\hline P. dovii & sp34 & 2.02653 & -1.34380 & 0.61312 \\
\hline C. spilopterus & $\mathrm{sp} 35$ & 0.75287 & 2.66401 & 0.47732 \\
\hline G. dormitor & $\mathrm{sp} 36$ & 0.42863 & 1.80053 & 1.49121 \\
\hline P. crocro & sp37 & 1.35095 & 1.42245 & 0.26824 \\
\hline R. bouchellei & sp38 & 0.89615 & -0.22528 & 1.85895 \\
\hline R. guatemalensis & sp39 & -0.35242 & -0.22367 & 3.15655 \\
\hline R. nicaraguensis & $\mathrm{sp} 40$ & -0.08160 & 0.50777 & 0.03769 \\
\hline A. aeneus & $\mathrm{sp} 41$ & 0.12985 & 0.43079 & 1.25826 \\
\hline P. gillii & $\mathrm{sp} 42$ & 0.49602 & 0.72772 & -1.78097 \\
\hline S. altum & $\mathrm{sp} 43$ & -0.75263 & -0.83560 & -0.39572 \\
\hline A. monticola & $\mathrm{sp} 44$ & -0.40950 & 1.06115 & -0.98200 \\
\hline B. costaricensis & $\mathrm{sp} 45$ & -0.68035 & -0.51359 & 0.31552 \\
\hline A. alfari & $\mathrm{sp} 46$ & -0.54493 & 2.88596 & -0.09607 \\
\hline J. pichardi & $\mathrm{sp} 47$ & -0.66620 & 1.34073 & -0.23900 \\
\hline R. laticauda & sp48 & -0.86128 & -0.59272 & 0.09769 \\
\hline A. banana & sp49 & -1.00923 & -0.17424 & 3.36045 \\
\hline H. nematopus & $\mathrm{sp} 50$ & -0.87671 & -0.73830 & 3.36640 \\
\hline G. nudus & sp51 & -0.87482 & -2.09329 & -0.87244 \\
\hline C. septemfasciatus & $\mathrm{sp} 52$ & -0.42195 & -2.05814 & 0.08894 \\
\hline P. annectens & sp53 & -0.64492 & 1.06085 & -3.53822 \\
\hline Boca Pacuare & St1 & 1.61581 & -0.23357 & 0.11593 \\
\hline Estero Mondonguillo & St2 & 1.40430 & -0.21505 & 0.17381 \\
\hline Estero Chiquero & St3 & 1.14189 & -0.05434 & 0.13695 \\
\hline Las Vegas & St4 & 0.26937 & 0.61356 & -0.05608 \\
\hline Freeman & St5 & 0.66821 & 1.26415 & 0.29292 \\
\hline Indiana III & St6 & -0.01281 & 0.38180 & 0.58073 \\
\hline Pacuarito & St7 & -0.16532 & 0.26358 & 0.33749 \\
\hline Betania & St8 & -0.24948 & 0.06625 & 0.33324 \\
\hline Tres Equis & St9 & -0.43044 & 0.10080 & -0.06737 \\
\hline Q. Sartén & St10 & -0.50544 & 0.46623 & -0.48852 \\
\hline La Cruz & St11 & -0.34008 & 0.26358 & 0.26151 \\
\hline R. Pacayitas & St12 & -0.62945 & -0.15472 & -0.60618 \\
\hline R. Cabeza de Buey & St13 & -0.64322 & -0.28812 & -0.43437 \\
\hline Bajo la Hondura & St14 & -0.48542 & -0.30474 & -0.11087 \\
\hline R. Peje & St15 & -0.68954 & -0.41552 & -0.44868 \\
\hline Q. Grande & St16 & -0.28579 & 0.56079 & -0.05054 \\
\hline R. Platanillo & St17 & 0.28007 & 0.47181 & -1.51597 \\
\hline Bajo Pacuare & St18 & -0.63351 & -0.52907 & -0.27095 \\
\hline Paso Marcos & St19 & -0.54731 & -0.22995 & -0.50143 \\
\hline $\mathrm{T}^{\circ} \mathrm{C}$ & - & 0.87804 & 0.25727 & 0.51790 \\
\hline $\operatorname{Depht}(\mathrm{m})$ & - & 0.76021 & -0.35799 & 0.34647 \\
\hline Velocity $(\mathrm{m} / \mathrm{s})$ & - & -0.77507 & -0.11704 & 0.07052 \\
\hline
\end{tabular}


TABLE 5

Average values and standard deviations for captures per sampling session and standard length for the first ten captured fish species according to sector of the Río Pacuare watershed. Sampling period May 2004 -May 2005.

\begin{tabular}{|c|c|c|c|c|c|c|}
\hline \multirow{2}{*}{ Species } & \multirow{2}{*}{ Variable } & \multicolumn{4}{|c|}{ Average \pm standard deviation } & \multirow{2}{*}{ Total } \\
\hline & & river mouth & lower reach & middle reach & upper reach & \\
\hline \multirow[t]{2}{*}{ Astyanax aeneus } & Capture & $35.1 \pm 32.9$ & $51.9 \pm 44.7$ & $25.1 \pm 32.4$ & $5.7 \pm 4.2$ & $32.4 \pm 37$ \\
\hline & $\mathrm{LS} \mathrm{cm}$ & $5.4 \pm 1.6$ & $5.7 \pm 0.9$ & $7.8 \pm 0.7$ & $7.7 \pm 1.5$ & $6.6 \pm 1.5$ \\
\hline \multirow[t]{2}{*}{ Poecilia gillii } & Capture & $11.8 \pm 7.5$ & $5.8 \pm 3.9$ & $11.0 \pm 12.1$ & $15.5 \pm 14$ & $10.0 \pm 9.1$ \\
\hline & $\mathrm{LS} \mathrm{cm}$ & $5.7 \pm 0.6$ & $4.8 \pm 0.8$ & $4.9 \pm 0.6$ & $4.7 \pm 1.4$ & $5.0 \pm 0.9$ \\
\hline \multirow[t]{2}{*}{ Sicydium altum } & Capture & & $31.4 \pm 23.9$ & $69.0 \pm 74$ & $37.4 \pm 21.8$ & $49.2 \pm 52.6$ \\
\hline & $\mathrm{LS} \mathrm{cm}$ & & $6.6 \pm 1.4$ & $8.3 \pm 0.7$ & $8.6 \pm 0.4$ & $8.0 \pm 1.2$ \\
\hline \multirow[t]{2}{*}{ Agonostomus monticola } & Capture & & $15.5 \pm 18.8$ & $30.2 \pm 19.4$ & $5.8 \pm 7.6$ & $18.3 \pm 19.1$ \\
\hline & $\mathrm{LS} \mathrm{cm}$ & & $7.5 \pm 4$ & $9.0 \pm 1.4$ & $10.3 \pm 1.9$ & $8.8 \pm 2.9$ \\
\hline \multirow[t]{2}{*}{ Brycon costaricensis } & Capture & & $5.3 \pm 4$ & $13.1 \pm 8.4$ & $3.0 \pm 2.6$ & $8.8 \pm 7.6$ \\
\hline & $\mathrm{LS} \mathrm{cm}$ & & $7.6 \pm 0.9$ & $11.1 \pm 3$ & $13.2 \pm 5.6$ & $10.3 \pm 3.5$ \\
\hline \multirow[t]{2}{*}{ Rhamdia laticauda } & Capture & & $7.0 \pm 10.4$ & $12 \pm 9.5$ & $4.6 \pm 2.3$ & $8.3 \pm 8.1$ \\
\hline & $\mathrm{LS} \mathrm{cm}$ & & $13.2 \pm 1.9$ & $10.4 \pm 0.6$ & $10.8 \pm 1.3$ & $11.1 \pm 1.6$ \\
\hline \multirow[t]{2}{*}{ Joturus pichardi } & Capture & & $6.0 \pm 7.4$ & $3.6 \pm 2.5$ & 4.0 & $4.3 \pm 4.2$ \\
\hline & $\mathrm{LS} \mathrm{cm}$ & & $13.8 \pm 9.2$ & $13.6 \pm 5.8$ & 19.5 & $14.1 \pm 6.5$ \\
\hline \multirow[t]{2}{*}{ Roeboides bouchellei } & Capture & $7 \pm 8.2$ & $5.2 \pm 4.8$ & & & $6.0 \pm 6.3$ \\
\hline & $\mathrm{LS} \mathrm{cm}$ & $7.5 \pm 2.3$ & $7.6 \pm 0.9$ & & & $7.6 \pm 1.6$ \\
\hline \multirow[t]{2}{*}{ Pomadasys crocro } & Capture & $22.5 \pm 0.7$ & $7.5 \pm 6.6$ & & & $11.3 \pm 8.9$ \\
\hline & $\mathrm{LS} \mathrm{cm}$ & $6.7 \pm 1.7$ & $6.8 \pm 0.8$ & & & $6.7 \pm 0.9$ \\
\hline \multirow[t]{2}{*}{ Atherinella milleri } & Capture & $13.5 \pm 15.3$ & 3.0 & & & $12 \pm 14.5$ \\
\hline & $\mathrm{LS} \mathrm{cm}$ & $8.8 \pm 1.8$ & 10.5 & & & $9.0 \pm 1.7$ \\
\hline
\end{tabular}

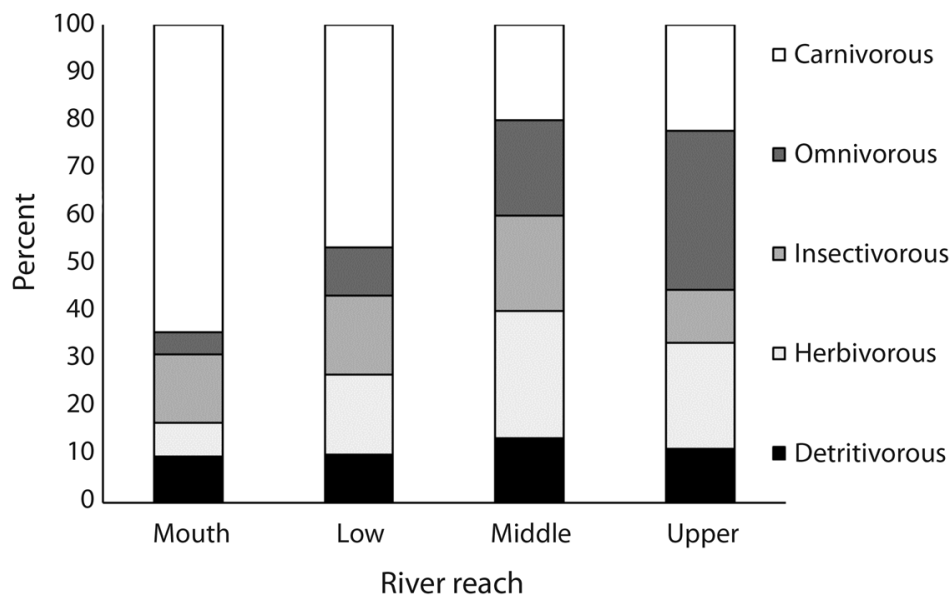

Fig. 9. Percent distribution of number of fish species according to trophic guilds and elevational reaches in the Río Pacuare. Period 2004-2005.

monticola in the channel of Las Vegas, at the border between the river mouth and the lower section. Also, most of the younger individuals of $J$. pichardi were found in Betania in the same months. These individuals measured less than six centimeters, and for this species we never observed schooling or massive movement upstream. 


\section{DISCUSSION}

Nineteen sites, grouped in four elevation reaches in the Río Pacuare, were sampled with the objective of describing the distribution and composition of its fish fauna and patterns of alpha and beta diversity along an elevational gradient. Correlations between fish presence and physical factors of the habitat and general ecology observations for the most abundant species were also assessed. Although it is possible to identify groups of species characteristic of each river reach, it doesn't mean that they are isolated from each other, since natural drift and elevational movements of some species during their life cycle, especially S. altum, A. monticola and $J$. pichardi, are key processes linking the whole watershed.

Fish assemblages: Our study distinguished a fish assemblage comprised of 42 species inhabiting the river mouth, where riverine and estuarine species share these waterways characterized by deep channels, soft substrates, high temperature and slow currents habitats. Moving upriver, we identified a transition sector between assemblages of lower and higher elevations. Within this sector, 22 species are shared with the river mouth and 15 with elevations above 100 m.a.s.l. The next assemblage consists of 15 species that can be related to the variation of habitat type, especially within a heterogeneous hard substrate. At elevations above 500 m.a.s.l., only nine species are found, comprising the fish assemblage that is well adapted to fast flowing water and lower temperature. Overall, we observed a similar pattern of dominance by the same and relatively few species, which are $S$. altum, A. aeneus, $A$. monticola, $P$. gillii and $R$. laticauda, including $J$. pichardi which is associated to the strong currents of the main channel. The habitat preference of $J$. pichardi make it a difficult fish to catch, and for this reason it was probably underestimated by our capture methods.

Some tributaries of Río Pacuare, in particular in its middle and upper reaches, flow over an irregular topography and steep slopes, which make them susceptible to high water velocities and alterations on the river bed during heavy rains. These conditions limit colonization by fishes from the main channel into these tributaries, like Quebrada La Cruz, Río Pacayitas and Río Platanillo, and partially explain the distinction between main channel and tributaries ichthyological communities. Seasonal strong flows cause the "reset" of tropical aquatic communities and have been assessed by Gilliam, Fraser, \& Alkins-Koo (1993), Pringle \& Hamazaki (1997), Jackson, Peres-Neto, \& Olden (2001), Boyero \& Bosh (2004), Buss, Baptista, Nessimian, \& Egler (2004).

Species diversity: According to our results, in the Río Pacuare the total fish fauna diversity is found within the first 500 m.a.s.l. Even though the elevation gradient studied does not cover the theoretical natural distribution for a few native fish, which have been reported to reach up to 1500 m.a.s.l. (Bussing, 1998, Angulo et al., 2013), a total of four fish species in Río Pacuare are expected to reach at least to that altitude. Based on the results of the present study, these species may include $S$. altum, $A$. monticola, R. laticauda and J. pichardi.

Elevation shows an inverse effect on species diversity. We observed a monotonic decrease in species richness with increasing elevation, with a drastically lower number of species in the upper reach of the Río Pacuare. Surveys in Andean rivers reported a similar pattern of fish assemblages (Jaramillo et al., 2010; Carvajal et al., 2015; De La Barra et al., 2015). In the Río Pacuare, species turnover increases with elevation, while nestedness decreases Turnover was dominated by the loss of species rather than gain of species; the higher species loss was detected between the river mouth and the lower river reach.

One hypothesis about the origin and distribution of the freshwater fish fauna in the Caribbean versant of Costa Rica, proposes that species richness is higher in areas located adjacent to centers of high diversity (Bussing, 1998; Matamoros et al., 2014). Accordingly, it appears that the fish fauna of Río Pacuare is a 
result of species dispersal from northern habitats towards the south, reaching all the way to the Bocas region in Panamá.

For that reason, it is expected that fish colonize first the lower reaches and then move up along the rivers, were the slope of the main channel, natural barriers like topographic drops and falls, as well as the flow velocity, are physical factors that filter the number of species that can be found at higher elevations. Given that this part of the Central America isthmus is relatively geologically young (Denyer, Alvarado, \& Aguilar, 2000), as opposed to the Andean region, there is no endemic ichthyofauna in the upper mountain regions (Bussing, 1998; Angulo et al., 2013) as is the case in the South American mountain chain.

Ecological traits: As we mentioned previously, the type of fish habitats changes with elevation, and with it, the species composition and their life-history strategies. Our results suggest that the distribution of each species along the elevation gradient is closely related to their body morphology, ecology and specific adaptations to overcome strong currents (Piet, 1998; Svanbäck, 2004; Hoagstrom \& Berry, 2008). For example, the distribution of $S$. altum coincides with its benthic dwelling habit: pelvic fins modified as a sucker allow them to colonize a wide spectrum of microhabitats in fast flowing rivers with a hard substratum (Bussing, 1998). We observed that adults were absent from soft bottom sites at the lower reach and near the river mouth, where filamentous algae, their main food source, cannot grow (Bussing, 1998; Instituto Costarricense de Electricidad (ICE), 2005). The massive upstream migration of juveniles of this species during months of low discharge that we witnessed has been also documented in other rivers in Costa Rica and the Caribbean region in general (Gilbert \& Kelso, 1971; McDowall, 1997; Fièvet, Dolèdec, \& Lim, 2001). These migrations are characteristic of the amphidromous reproductive strategy displayed by several tropical freshwater fishes (McDowall 2007; Smith, 2013).
Within the Characidae, A. aeneus was the most abundant species along the elevational range in our study. Adults are able to swim upstream against fast currents, and as generalists, they eat a wide variety of food (Bussing \& López, 1977; López, 1978; Bussing, 1998). B. costaricensis was also observed over a wide elevational range, and it is the second largest species that can be found in the middle and upper reaches of the Río Pacuare. This versatile generalist is also a potential seed disperser for some trees within the riparian ecosystem, as described by Burcham (1988), Horn (1997) in the Caribbean rivers of Costa Rica.

Both mullet species are classified as rheophilic: fast-flowing waters stimulate them to swim up river, and their fusiform body shape enables them to swim against strong currents, sometimes jumping over small falls and obstacles while reaching higher reaches of river. $A$. monticola is widely distributed in Costa Rica rivers (Bussing \& López, 1977; Bussing, 1998). This species is amphidromous and is mainly carnivorous, but can also be found consuming algae and other plant material, which make them a key and versatile species in the riverine ecosystem (Cruz, 1987; Navarro, 1992; Phillip, 1993; Torres \& Lyons, 1999; ICE, 2005; Cotta \& Umaña, 2010; Smith, 2013). J. pichardi is restricted to the Caribbean versant, is the largest fish that inhabits the middle and upper reaches and is an herbivore, feeding primary on periphyton and filamentous algae (Cruz, 1987; Bussing, 1998; ICE, 2005). As a specialist, it is vulnerable to habitat alterations like changes in water turbidity or high sediment loads that may reduce periphyton growth.

According to Bussing (1998), P. gillii is one of the most common freshwater fish of Costa Rica, found in a wide variety of habitats and elevations. These fish feed on detritus and periphyton algae, usually forming large groups in pools and river margins, since they are not strong swimmers (Bussing \& López, 1977). These fishes are small (less than $10 \mathrm{~cm} \mathrm{SL}$ ), are viviparous and have continuous reproduction during the year; For these reasons, it is likely that their abundance was under-estimated in 
our study because we did not efficiently capture this species with our net mesh size. Nonetheless, there was a tendency to find larger individuals in the lower reaches and river mouth in comparison with the rest of the watershed, perhaps as a result of the comparatively greater food abundance and higher habitat stability in the lower habitats (ICE, 2005).

Members of the Heptateridae (long-whiskered catfishes) showed a wide elevational distribution in Río Pacuare, although $R$. laticauda was the most abundant at higher elevations. This result is consistent with other observations made in Costa Rican rivers (Bussing, 1998). As benthonic species, they dwell in a wide range of water velocities in the watershed. In the case of the members of the Cichlidae, they were found for the most part in sites of the lower reaches, below 100 m.a.s.l., particularly in sites with low water velocity, with abundant vegetation and logs lying on the river bottom. This pattern reflects that the majority of Cichlidae species that we caught are not well-adapted to withstand fast flowing waters (Winemiller, Kelso-Winemiller, \& Brenkert, 1995; Bussing, 1998; Wright \& Flecker, 2004; Anderson et al., 2006a).

Babler \& Babler (1980), Nordlie (1981), and Strydom (2002), describe a higher species richness at the river mouth and lower reaches of tropical rivers based on the use of these areas as centers of reproduction and hatcheries for both, marine and freshwater species, resulting in a high density of juvenile life stages. It seems like this high availability of food sources, favors a predominance of carnivorous fish species (Burcham, 1988; Aranha, Takeuti, \& Yoshimura, 1998; Fièvet et al., 2001; Winemi1ler \& Leslie 1992; Sánchez \& Rueda, 1999; Hoeinghaus, Layman, Arrington, \& Winemiller, 2003). Some examples of these species at Río Pacuare include members of Centropomidae, Haemulidae, Lutjanidae and Eleotridae.

At the lower reaches, there are also some common species that feed on detritus. Examples of these detritivorous species include Gerreidae (Sánchez, Galvis, \& Victoriano, 2003; Hoagstrom \& Berry, 2008), the loricarid fish
Hemiancistrus aspidolepis and some members of Cichlidae like Vieja maculicauda. In the middle and upper reaches of the watershed, the dominant feeding group is "herbivorous", especially where the hard-rocky substrate allows periphyton and filamentous algae growth (Sánchez et al., 2003; Hoagstrom \& Berry, 2008). Examples of this feeding guild include $S$. altum and $J$. pichardi. In these river reaches, the riverine vegetation includes a high diversity of trees and other plants whose flowers, fruits and leaves represent food sources for fish (Sánchez et al., 2003), such as members of the Characidae family, and in particular adults of B. costaricensis. Some of the species that are abundant, and widely distributed along the watershed, can be classified as "omnivorous" or "generalist" (Sánchez et al., 2003; Hoagstrom \& Berry, 2008), as the case of $A$. aeneus and A. monticola.

In terms of reproductive strategies, most of the species with a wide elevation distribution in the Río Pacuare are characterized by an " $r$ " strategy, in which females produce thousands of eggs and juveniles later drift with the current downstream (Roldán, 1992; Bussing, 1998; Smith \& Smith, 2001). Therefore, we expect them to be distributed throughout the watershed, as observed for S. altum, A. aeneus, A. monticola, R. laticauda and J. pichardi. On the contrary, those species with a "K" strategy tend to concentrate in specific sites within the watershed, as exemplified by members of the Cichlidae (Winemiller et al., 1995; Bussing, 1998; Smith \& Smith, 2001).

Taking into account the fish environmental guilds (EG) classification proposed by Welcomme, Winemiller, \& Cowx (2006), and the later work on stream fish assemblage structure by Hoeinghaus, Winemiller, \& Birnbaumm (2007), the family Gobiidae would belong to the estuarine semi-anadromous EG. Nevertheless, our observations suggest that $S$. altum and other members of the Gobiidae that inhabit Costa Rican rivers should be better classified as amphidromous EG, because they live in estuaries only during their early larval stages. 
In the case of Characidae, $A$. aeneus is classified into the plesiopotamic EG, even though, owing to its ecological plasticity, are good candidates to be included in the eurytopic EG, which include all generalist species with flexible behavior. Another example is B. costaricensis: the ecology of its juveniles corresponds to the plesiopotamic EG, whereas adults correspond to the generalist eurytopic EG (Welcomme et al., 2006).

For the freshwater Mugilidae species, $A$. monticola and $J$. pichardi, both belong to the EG eupotamic pelagophilic in the original classification. In our study, these species were found in the main river channel, with rapid well-oxygenated waters, and their eggs and larvae drift downstream to the lower reaches where they complete their development (Welcomme et al., 2006). Nevertheless, in the case of $J$. pichardi, adults also show characteristics typical of the EG of species that dwell in the rapids at the upper reaches of the watershed. In contrast, A. monticola presents reproductive characteristics associated with the amphidromous EG. The species $R$. laticauda is classified as plesiopotamonic; however, given its affinity to habitats at higher elevations and strong current velocities, this species could also be assigned to the riffle EG.

The ecology of $P$. gillii, and several middle-size species of the family Poeciliidae, are classified into the plesiopotamonic EG, which take advantage of habitats with slow currents and lateral channels that form seasonally during high flow periods. In the lower reaches and the river mouth, we found the EG estenohaline and euryhaline, as well as typically marine, opportunistic species, as proposed by Welcomme et al. (2006).

In conclusion, we found a monotonic richness decrease with elevation as has been described for other tropical rivers. Turnover was dominated by the loss of species rather than gain, and the highest species loss was detected between the river mouth and the lower river reach. A total of 7 species can be classified as typical or core species within the Río Pacuare (A. aeneus, S. altum, A. monticola,
P. gillii, B. costaricensis, R. laticauda and $J$. pichardi), representing the EG of generalist, amphidromous and eurytopic inhabiting rapids in the main channel. Consideration of habitat availability and the integration of ecomorphological, feeding and reproductive traits help to explain better the elevational distribution of the complete set of species observed. Further work is necessary to more completely ascribe the useful ecological guilds proposed by Welcomme et al. (2006) to the freshwater fishes of Costa Rica.

The present study constitutes a first step in documenting and understanding the distribution and composition of fish assemblages in a watershed that is relatively intact and reasonably well-conserved. Future work should involve the analysis of habitat preferences of the species at a smaller scale, which is necessary to improve our understanding of the population dynamics of freshwater fish species. We recommend performing a larger sampling effort, including fishing methods and gear that allow the catch of a wider range of body sizes, as well as including sites above 650 m.a.s.1., since some species might be able to reach higher elevations in this watershed.

\section{ACKNOWLEDGMENTS}

The development of this study was made possible through the logistic and financial support provided by the Instituto Costarricense de Electricidad (ICE), the Research Center for Marine Sciences and Limnology (CIMAR) and the School of Biology of the University of Costa Rica. We are very grateful to Susy Segura, Danny Zamora, Jeymer Morales, Carlos Méndez, William Jiménez, Daniel Ortega and Fabio Víquez for their enormous support during field work. Also to Rita Vargas, Ana Rosa Ramírez, William Bussing (↔) and Myrna López for all of their collaboration during the process of fish identification. Special thanks are owed to Helena Molina, Francis Joyce and the anonymous reviewers whose comments and observations help us to improve the article. 


\section{RESUMEN}

Ensambles de peces y sus características ecológicas a lo largo de un gradiente altitudinal del río Pacuare, Costa Rica. Entre mayo del 2004 y mayo del 2005, se desarrolló una campaña de muestreo en 19 sitios agrupados en cuatro tramos de elevación abarcando desde la desembocadura hasta los 650 m.s.n.m en el río Pacuare, de la vertiente Caribe de Costa Rica. Se evaluó el cambio en la distribución y composición de la fauna íctica, así como los patrones de diversidad alfa y beta a lo largo de un gradiente altitudinal. Adicionalmente se incluye un análisis de las preferencias de hábitat, gremio trófico, grupo funcional y ecología general para las especies más abundantes. Todos los peces capturados se clasificaron en 22 familias, 43 géneros y 53 especies. La familia más abundante fue Characidae, seguida de Gobiidae, Mugilidae, Poeciliidae y Heptapteridae, en total representando el $87.9 \%$ de todos los individuos registrados. La elevación mostró un efecto inverso en la diversidad de especies, observamos una disminución monotónica en la riqueza de especies al incrementar la elevación $(\mathrm{p}<0.05)$, tal y como ha sido reportado en otros ríos tropicales. De acuerdo a nuestros resultados, en el río Pacuare la totalidad de la diversidad íctica se encuentra en los primeros 500 m.s.n.m. El reemplazo (turnover) de las especies se incrementa con la elevación, mientras que la pérdida de especies (nestedness) disminuye. El reemplazo de las especies estuvo dominado por la pérdida más que por la adición de nuevas especies, la mayor pérdida de especies se presenta entre la desembocadura y el tramo bajo ( $<100$ m.s.n.m.). Un total de 7 especies de peces pueden ser clasificadas como las típicas o principales a lo largo del gradiente de elevación. La disponibilidad de hábitat y la integración de rasgos eco-morfológicos, alimentarios y reproductivos permiten una mejor explicación de la distribución del grupo completo de especies registradas. Aunque es posible identificar grupos de especies características de cada tramo del río, no quiere decir que se encuentren aisladas unas de otras, la deriva natural y los movimientos a lo largo del río por parte de algunas especies durante su ciclo de vida, especialmente Sicydium altum, Agonostomus monticola y Joturus pichardi, son procesos claves que unen la totalidad de la cuenca. El presente estudio constituye un primer paso en la documentación y entendimiento de la distribución y composición de las asociaciones de peces en una cuenca que se encuentra relativamente intacta y bien conservada.

Palabras clave: Río Pacuare, gradiente de elevación, peces de agua dulce, vertiente Caribe.

\section{REFERENCES}

Albert, J. S., \& Reis, R. E. (2011). Introduction to Neotropical Freshwaters. In J. S. Albert \& R. E. Reis (Eds.). Historical Biogeography of Neotropical Freshwater
Fishes (pp. 2-19). London, England: University of California Press.

Anderson, E. P., Freeman, M. C., \& Pringle, C. M. (2006a). Ecological consequences of hydropower development in Central America: impacts of small dams and water diversion on neotropical stream fish assemblages. River Research and Applications, 22(4), 397-411. doi:10.1002/rra.899

Anderson, E. P., Pringle, C. M., \& Rojas, M. (2006b). Transforming tropical rivers: an environmental perspective on hydropower development in Costa Rica. Aquatic Conservation: Marine and Freshwater Ecosystems, 16(7), 679-693. doi:10.1002/aqc.806

Angulo, A., Garita-Alvarado, C. A., Bussing, W. A., \& López, M. I. (2013). Annotated checklist of the freshwater fishes of continental and insular Costa Rica: additions and nomenclatural revisions. Check List, 9(5), 987. doi:10.15560/9.5.987

Aranha, J. M. R., Takeuti, D. F., \& Yoshimura, T. M. (1998). Habitat use and food partitioning of the fishes in a coastal stream of Atlantic Forest, Brazil. Revista de Biología Tropical, 46(4): 951-959.

Blaber, S. J., \& Blaber, T. G. (1980). Factors affecting the distribution of juvenile estuarine and inshore fish. Journal of Fish Biology, 17(2), 143-162. doi:10.1111/j.1095-8649.1980.tb02749.x

Baselga, A., \& Orme, C. D. (2012). Betapart: An R package for the study of beta diversity. Methods in Ecology and Evolution, 3(5), 808-812. doi:10.1111/j.2041-210x.2012.00224.x

Beard, F. (1989). The feeding ecology of tropical freshwater fish in three Costa Rican rivers (bachelor's thesis). Birmingham, UK: Birmingham University.

Boyero, L., \& Bosch, J. (2004). Multiscale spatial variation of stone recolonization by macroinvertebrates in a Costa Rican stream. Journal of Tropical Ecology, 20(01), 85-95. doi:10.1017/s0266467403001019

Burcham, J. (1988). Fish communities and environmental characteristics of two lowland streams in Costa Rica. Revista de Biología Tropical, 36(2A), 273-285.

Buss, D. F., Baptista, D. F., Nessimian, J. L., \& Egler, M. (2004). Substrate specificity, environmental degradation and disturbance structuring macroinvertebrate assemblages in neotropical streams. Hydrobiologia, 518(1-3), 179-188. doi:10.1023/b:hydr.0000025067.66126.1c

Bussing, W. A. (1998). Peces de las aguas continentales de Costa Rica. Revista de Biología Tropical, 46(Suppl. 2), $1-504$.

Bussing, W. A., \& López, M. I. (1977). Distribución y aspectos ecológicos de los peces de las cuencas 
hidrográficas de Arenal, Bebedero y Tempisque, Costa Rica. Revista de Biología Tropical, 25, 13-37.

Carvajal-Quintero, J. D., Escobar, F., Alvarado, F., VillaNavarro, F. A., Jaramillo-Villa, Ú., \& MaldonadoOcampo, J. A. (2015). Variation in freshwater fish assemblages along a regional elevation gradient in the northern Andes, Colombia. Ecology and Evolution, 5(13), 2608-2620. doi:10.1002/ece3.1539

Cayuela, L., Gotelli, N. J., \& Colwell, R. K. (2015). Ecological and biogeographic null hypotheses for comparing rarefaction curves. Ecological Monographs, 85(3), 437-455. doi:10.1890/14-1261.1

Chao, A., Gotelli, N. J., Hsieh, T. C., Sander, E. L., Ma K. H., Colwell, R. K., \& Ellison, A. M. (2014) Rarefaction and extrapolation with Hill numbers: a framework for sampling and estimation in species diversity studies. Ecological Monographs, 84, 45-67.

Clarke, K. R., \& Warwick, R. M. (1994). Change in marine communities: An approach to statistical analysis and interpretation. Plymouth, UK: Natural Environment Research Council.

Colwell, R. K. (2013). EstimateS, Version 9.1: Statistical Estimation of Species Richness and Shared Species from Samples (Software and User's Guide). Retrieved from http://priede.bf.lu.lv/ftp/pub/GIS/datu_analiize/EstimateS/EstimateSUsersGuide_091.htm

Cotta, R. T., \& Umaña V. G. (2010). Distribution of Agonostomus monticola and Brycon behreae in the Río Grande de Térraba, Costa Rica and relations with water flow. Neotropical Ichthyology, 8(4), 841-849.

Cruz, G. A. (1987). Reproductive biology and feeding habits of cuyamel, Joturus pichardi and tepemechín, Agonostomus monticola (Pisces; Mugilidae) from Río Plátano, Mosquitia, Honduras. Bulletin Marine Science, 40, 63-72.

De La Barra, E. D., Zubieta, J., Aguilera, G., Maldonado, M., Pouilly, M., \& Oberdorff, T. (2016). ¿Qué factores determinan la distribución altitudinal de los peces de ríos tropicales andinos? Revista de Biología Tropical, 64(1), 157. doi:10.15517/rbt.v64i1.18576

Denyer, P., Alvarado, G. E. \& Aguilar, T. (2000). Historia geológica. In P. Denyer \& S. Kussmaul (Eds.). Geología de Costa Rica (pp. 155-167). Cartago, Costa Rica: Editorial Tecnológica de Costa Rica.

Fièvet, E., Dolèdec, S. \& Lim, P. (2001). Distribution of migratory fishes and shrimps along multivariate gradients in tropical island streams. Journal of Fish Biology, 59, 390-402.

Gilbert, C. R., \& Kelso, D. P. (1971). Fishes of the Tortuguero area, Caribbean Costa Rica. Bulletin of Florida State Museum, Biological Sciences, 16(1), 1-57.
Gilliam, J. F., Fraser, D. F., \& Alkins-Koo, M. (1993). Structure of a Tropical Stream Fish Community: A Role for Biotic Interactions. Ecology, 74(6), 18561870. doi:10.2307/1939943

Hammer, Ø., Harper, D. A. T., \& Ryan, P. D. (2001). PAST: Paleontological Statistics Software Package for Education and Data Analysis. Palaeontologia Electronica, 4(1): 9. Retrieved from http://folk.uio. no/ohammer/past.

Hoagstrom, C. W., \& Berry, C. R. (2008). Morphological diversity among fishes in a Great Plains river drainage. Hydrobiologia, 596, 367-386. doi: 10.1007/ s10750-007-9110-5

Hoeinghaus, D. J., Layman, C. A., Arrington, D. A., \& Winemiller, K. O. (2003). Spatiotemporal variation in fish assemblage structure in tropical floodplain creeks. Enviromental Biology of Fishes, 67, 379-387.

Hoeinghaus, D. J., Winemiller, K. O., \& Birnbaum, J. S. (2007). Local and regional determinants of stream fish assemblage structure: inferences based on taxonomic vs. functional groups. Journal of Biogeography, 34(2), 324-338. doi:10.1111/j.1365-2699.2006.01587.x

Horn, M. H. (1997). Evidence for dispersal of fig seeds by the fruit-eating characid fish Brycon guatemalensis Regan in a Costa Rican tropical rain forest. Oecologia, 109(2), 259-264. doi:10.1007/s004420050081

Hsieh, T. C., Ma, K. H., \& Chao, A. (2016) iNEXT: An R package for interpolation and extrapolation of species diversity (Hill numbers). Methods in Ecology and Evolution 2016, 7, 1451-1456.

Instituto Costarricense de Electricidad. (2005). Proyecto de desarrollo hidroeléctrico Pacuare, Costa Rica. Actualización del estudio de impacto ambiental. Expediente Administrativo 118-97 SETENA. Memoria Resoluciones 342-2004 y 492-2005. San José, Costa Rica: SETENA.

Instituto Costarricense de Electricidad. (2006). Unidad de Manejo de cuencas. Informe de labores 2006. Retrieved from http://www.grupoice.com/esp/ele/ manejo_cuencas/index.html

Jackson, D. A., Peres-Neto, P. R., \& Olden, J. D. (2001). What controls who is where in freshwater fish communities - the roles of biotic, abiotic, and spatial factors. Canadian Journal of Fisheries and Aquatic Sciences, 58(1), 157-170. doi:10.1139/cjfas-58-1-157

Jaramillo-Villa, U., Maldonado-Ocampo, J. A., \& Escobar, F. (2010). Altitudinal variation in fish assemblage diversity in streams of the central Andes of Colombia. Journal of Fish Biology, 76(10), 2401-2417. doi:10.1111/j.1095-8649.2010.02629.x

Krebs, C. J. (1994). Ecological methodology. CA, USA: Benjamin/Cummings, Addison Wesley Longman. 
López, S. M. I. (1978). Migración de la sardina Astyanax fasciatus (Characidae) en el río Tempisque, Guanacaste, Costa Rica. Revista de Biología Tropical, 26(1), 261-275.

Matamoros, A. W., McMahan, C. D., Chakrarty, P., Albert, J. S. \& Schaefer J. F. 2014. Derivation of the Freshwater fish fauna of Central America revisited: Myers's hypothesis in the twenty first century. Cladistics, 31(2), 177-188. Doi:10.1111/cla.12081.

McDowall, R. M. (1997). The evolution of diadromy in fishes (revisited) and its place in phylogenetic analysis. Reviews in Fish Biology and Fisheries, 7, 443-462.

Mcdowall, R. M. (2007). On amphidromy, a distinct form of diadromy in aquatic organisms. Fish and Fisheries, 8(1), 1-13. doi:10.1111/j.1467-2979.2007.00232.x

Meyer, G. S. (1966). Derivation of the Freshwater Fish Fauna of Central America. Copeia (4), 766-773.

Navarro, P. S. (1992). Biología, ecología y aprovechamiento de Agonostomus monticola, trucha de tierra caliente, en la Reserva de la Biósfera Sierra de Mazatlán, Jalisco, México (tesis de maestría). Heredia, Costa Rica: Universidad Nacional.

Nordlie, F. G. (1981). Feeding and reproductive biology of eleotrid fishes in a tropical estuary. Journal of Fish Biology, 18(1), 97-110. doi:10.1111/j.1095-8649.1981. tb03764.x

Phillip, D. A. (1993). Reproduction and feeding of the mountain mullet, Agonostomus monticola, in Trinidad, West Indies. Environmental Biology of Fishes, 37(1), 47-55. doi:10.1007/bf00000711

Piet, G. J. (1998). Ecomorphology of a size-structured tropical freshwater fish community. Enviromental Biology of Fishes, 51, 67-86.

Pringle, C. M., \& Hamazaki, T. (1997). Effects of Fishes on Algal Response to Storms in a Tropical Stream. Ecology, 78(8), 2432. doi:10.2307/2265904

R Development Core Team. (2008). R: A language and environment for statistical computing. Vienna, Austria: R Foundation for Statistical Computing. Retrieved from http://www.R-project.org

Rojas, N. 2011. Cuenca del Río Pacuare. San José, Costa Rica: MINAET-IMN-PNUD. Retrieved from http:// cglobal.imn.ac.cr/sites/default/files/documentos/ cuenca_rio_pacuare.pdf

Roldán P. G. A. (1992). Fundamentos de limnología neotropical. Medellín, Colombia: Editorial Universidad de Antioquia.
Sánchez, R. C., \& Rueda, M. (1999). Variación de la diversidad y abundancia de las especies ícticas dominantes en el Delta del Río Magdalena, Colombia. Revista de Biología Tropical, 47(4), 1067-1079.

Sánchez, R. M., Galvis, G., \& Victoriano, P. F. (2003). Relación entre características del tracto digestivo y los hábitos alimentarios de peces del Río Yucao, sistema del Río Meta (Colombia). Gayana (Concepción), 67(1), doi:10.4067/s0717-65382003000100010

Smith, W. E. (2013). Reproductive Ecology of Caribbean Amphidromous Fishes (Doctoral dissertation). Raleigh, North Carolina, USA: North Carolina State University.

Smith, R. L., \& Smith, T. M. (2001). Ecologia. Madrid, España: Pearson Educación.

Strydom, N. A. (2002). Dynamics of early stage fishes associated with selected warm temperate estuaries in South Africa (Doctoral dissertation). Grahamstown, South Africa: Rhodes University.

Svanbäck, R. (2004). Ecology and evolution of adaptive morphological variation in fish populations (Doctoral dissertation). Umeå, Sweden: Umeå University.

Torres- Navarro, C. I., \& Lyons, J. (1999). Diet of Agonostomus monticola (Pisces: Mugilidae) in the río Ayuquila, Sierra de Mazatlán Biosphere Reserve, México. Revista de Biología Tropical, 47(4),1087-1092.

Welcomme, R. L., Winemiller, K. O., \& Cowx, I. G. (2006). Fish environmental guilds as a tool for assessment of ecological condition of rivers. River Research and Applications, 22(3), 377-396. doi:10.1002/rra.914

Winemiller, K. O., \& Leslie, M. A. (1992). Fish assemblages across a complex, tropical freshwater/marine ecotone. Environmental Biology of Fishes, 34(1), 29-50. doi:10.1007/bf00004783

Winemiller, K. O., Kelso-Winemiller, L. C., \& Brenkert, A. L. (1995). Ecomorphological diversification and convergence in fluvial cichlid fishes. Environmental Biology of Fishes, 44(1-3), 235-261. doi:10.1007/ bf00005919

Wolter, C., \& Arlinghaus, R. (2003). Navigation impacts on freshwater fish assemblages: the ecological relevance of swimming performance. Reviews in Fish Biology and Fisheries, 13, 63-89.

Wright, J. P., \& Flecker, A. S. (2004). Deforesting the riverscape: the effects of wood on fish diversity in a Venezuelan piedmont stream. Biological Conservation, 120(3), 439-447. doi:10.1016/j.biocon.2004.02.022

Zar, J. H. (1999). Biostatistical analysis. Upper Saddle River, New Jersey, USA: Prentice Hall. 